\title{
Acervo de poesias
}

Acervo de poesias composto pelas seguintes: Poesia intitulada “O Novo Paradigma Emergente”, sem data de escrita determinada; Poesia intitulada "Uma Maneira de Pedir Fique Comigo!", sem data de escrita determinada.

Palavras-chave: Poesia.

\section{Poetry collection}

Poetry collection composed by the following: Poetry entitled "The New Emerging Paradigm", with no date of writing determined; Poetry titled "A Way of Asking Stay with Me!", with no date set.

Keywords: Poetry.

Topic: Registro de Obras Artísticas

Reviewed anonymously in the process of blind peer.
Received: 15/08/2019

Approved: 22/08/2019
Aluísio Vasconcelos de Carvalho (iD)

Faculdade Guaraí, Brasil

http://lattes.cnpq.br/5200758055263996

http://orcid.org/0000-0002-3793-3133

aluisiovasconcelos@gmail.com
Referencing this:

CARVALHO, A. V.. Acervo de poesias. Social Evolution, v.3, n.1, p.17-

19, 2019. DOI: http://doi.org/10.6008/CBPC2595-430X.2019.001.0004

DOI: 10.6008/CBPC2595-430X.2019.001.0004 


\section{OBRA}

\section{O novo paradigma emergente}

As práticas educacionais vêm transformando Por causa da diversidade Assim fica mais fácil aprender

E ter uma educação de qualidade

Diante de tanta cultura

É difícil se adaptar

Mas com criatividade

Nós podemos alcançar

No ensino é preciso

Englobar tudo o que sabemos

Buscar todas as fontes de conhecimento

Principalmente aquela em que vivemos

$O$ aluno é um agente

$\mathrm{Na}$ qual se pode dialogar

Sobre as questões que trouxer

Fazendo-o questionar

É papel do professor

Facilitar o conhecimento

Fazendo o aluno ver

As diferentes linhas de pensamento

Com as constantes mudanças do mundo Não devemos complicar

Mas usá-lo como referência

Para melhor ensinar

O currículo é importante

Para o conhecimento direcionar

Alcançando os objetivos

Uma nova metodologia aplicar
Antigamente $o$ aluno

Tinha os olhos vendados

Por não ter sua forma de expressão

E seus atos mecanizados

Agora tudo mudou

Tem acesso ao aprendizado

Buscando a sua autonomia

No ambiente civilizado

É preciso incentivar

Causar perturbação

Desenvolvendo no aluno

Constante transformação

A constituição aborda seriamente

A qualidade do ensino padronizado

É preciso melhorar as formas de execução

Da gestão educacional transformado

Desigualdade não é aceito

O ensino para todos primeiramente buscar

A visão de um futuro igualitário

Para o sucesso de todos alcançar

Não adianta a comunidade escolar

Querer o bem de todos e trabalhar sozinho

O país é representa a nação

De um povo bem sofrido

Por longas perdas e conquistas

Precisamos estar unidos. 
Uma maneira de pedir fique comigo!

Pensava que sonhos não existiam, Que amor era uma mera ilusão Que a Alegria era passageira E fria era a tal paixão.

A história muda o tempo

A maneira de se agir Nasce vida em abundância

E o despertar e o de sorrir

Minha história eu escrevo Com gotas de amor

Acrescento na minha alma

Efervescente de calor

Ninguém vive sozinho

Tão somente rejeitado

Eu escolhi mudar

A história do meu passado
Acrescentei Alegria

Esperança, Amor e Paz

Porque a pessoa que eu amo

Encontra-se na outra linha de traz

Não desistirei nunca

Porque não sem viver sem ela

Aprendi a depender da sua presença

Meu coração por ti martela

Seu nome é lindo e puro

Larissa de Melo é quem eu amo

Entrego-te o meu futuro

Por isso eu te chamo

Casa-se comigo

Por que eu te amo 